J. Clin. Chem. Clin. Biochem.

Vol. 24, 1986, pp. $871-875$

(C) 1986 Walter de Gruyter \& Co. Berlin. New York

\title{
Photometric Determination of Phospholipase A
}

\author{
By G. E. Hoffmann, D. Schmidt, B. Bastian and W. G. Guder \\ Institut für Klinische Chemie, Städtisches Krankenhaus München-Bogenhausen
}

(Received January 8/June 30, 1986)

Summary: A photometric method for the determination of phospholipase A is described, in which fatty acids are liberated from phosphatidylcholine and measured by a discontinuous enzymatic test. Optimal test conditions were evaluated using purified phospholipase $\mathbf{A}$ from human and porcine pancreas. The enzyme activities measured in normal human sera are in the range of 0 to $10 \mathrm{U} / 1$. Pathological values reach more than $100 \mathrm{U} / \mathrm{l}$. There is no correlation with the activities of lipase or amylase in cases of acute pancreatitis.

\section{Photometrische Bestimmungsmethode für Phospholipase A}

Zusammenfassung: Eine Methode zur photometrischen Bestimmung der Phospholipase A wird beschrieben, bei der aus Phosphatidylcholin freigesetzte Fettsäuren mit einem diskontinuierlichen enzymatischen Test nachgewiesen werden. Der Test wurde mit Hilfe gereinigter Phospholipase A aus dem Pankreas von Mensch und Schwein optimiert. Der vorläufige Referenzbereich für die katalytische Aktivitätskonzentration in menschlichen Seren liegt bei 0-10 U/1, pathologische Werte erreichen $100 \mathrm{U} / 1$ und mehr. Zu den Aktivitäten von Lipase und Amylase besteht keine gesicherte Korrelation.

\section{Introduction}

Phospholipases $A_{1}$ and $A_{2}$ liberate fatty acids from the alpha- or beta-position of various phospholipids such as phosphatidylcholine or phosphatidyl-ethanolamine. During experimental pancreatitis, the activities of both enzymes are elevated in blood serum (1). Especially the release of active phospholipase $A_{2}$ into the circulation seems to be associated with severe complications of pancreatic diseases $(2,3)$. Since this enzyme is able to split cellular and extracellular phospholipids, it may destroy essential organ structures and form cytotoxic lysocompounds. Furthermore, the liberation of polyunsaturated fatty acids, e. g. arachidonic acid, may lead to formation of highly active eicosanoid compounds.

We have developed a photometric method for the determination of phospholipase $A$ as quantified by the overall-liberation of long-chain fatty acids from soy-bean phosphatidylcholine. In the present paper, this new method is described in detail. Preliminary results have been published previously (4).

\section{Materials and Methods}

The following reagents and enzymes were used in this study:

Soy-bean phosphatidylcholine (batch no. 0835674), Roth, Karlsruhe.

Phospholipase $A_{2}$ from porcine pancreas, Boehringer, Mannheim.

Triton X-100, Sigma, St. Louis, USA.

Test kit for the enzymatic determination of fatty acids, Wako Chemicals, Osaka, Japan, including reagents and an oleic acid standard.

All other reagents were from Merck, Darmstadt.

A substrate emulsion, containing phosphatidylcholine, buffer, and activators was produced using a similar method to that described by Shakir (5):

Soy-bean phospatidylcholine $(0.3 \mathrm{~g})$ is dissolved in $15 \mathrm{ml}$ chloroform/methanol $(\mathrm{v} / \mathrm{v}=2+1)$ and $21 \mathrm{ml}$ diluted Triton $\mathrm{X}$ $100(5 \mathrm{~g} / 1)$ is added. The organic solvent is removed at $37^{\circ} \mathrm{C}$ by vigorous shaking on a whirl-mix under a stream of nitrogen until the milky emulsion becomes opalescent (5 to $10 \mathrm{~min}$ ). The resulting emulsion is stable for at least one week at $4{ }^{\circ} \mathrm{C}$. For preparation of the incubation mixture, the emulsion is diluted at room temperature with an equal volume $(21 \mathrm{ml})$ of an appropriate buffer (see results section) containing sodium deoxycholate $(2 \mathrm{mmol} / \mathrm{l}) . \mathrm{CaCl}_{2}(340 \mathrm{mmol} / \mathrm{l})(0.5 \mathrm{ml})$ is added to give a final concentration of $4 \mathrm{mmol} / \mathrm{l}$. 
A partially purified phospholipase preparation was obtained from autopsic human pancreas using the first two steps (heat treatment at acid $\mathrm{pH}$ and ammonium sulphate fractionation) of the method described by Eskola et al. (6).

The phospholipase A assay was performed according to the following reaction scheme:

Phosphatidylcholine $+\mathrm{H}_{2} \mathrm{O} \rightarrow$ Fatty acid + Lysophosphatidylcholine

Fatty acid + ATP + CoASH $\rightarrow$ Acyl-CoA + AMP + PP Acyl-CoA $+\mathrm{O}_{2} \rightarrow$ 2,3-trans-Enoyl-CoA $+\mathrm{H}_{2} \mathrm{O}_{2}$ $\mathrm{H}_{2} \mathrm{O}_{2}+$ Chromogen $\rightarrow \mathrm{H}_{2} \mathrm{O}+$ "Red Quinone Colour"

Enzyme-containing sample $(0.1 \mathrm{ml})$ is incubated with $1 \mathrm{ml}$ phosphatidylcholine emulsion at $37^{\circ} \mathrm{C}$. At defined time intervals, $0.2 \mathrm{ml}$ aliquots of this mixture are transferred to a new test tube containing $0.2 \mathrm{ml}$ of a stop-reagent $(0.05 \mathrm{~mol} / \mathrm{l}$ phosphate buffer, pH 5.5 and $6 \mathrm{mmol} / \mathrm{l}$ EDTA). Subsequently, fatty acids are determined using the NEFA-test kit according to the manufacturers instructions, with an altered sample-reagent-ratio ( $0.04 \mathrm{ml}$ sample, $0.25 \mathrm{ml}$ reagent $\mathrm{A}, 0.50 \mathrm{ml}$ reagent $B$ ).

1 Unit $(U)$ was defined as the liberation of $1 \mu \mathrm{mol}$ fatty acid per min. In order to detect the low phospholipase A activities present in normal human sera (see results section), fatty acid liberation was followed over $1 \mathrm{~h}$ of incubation. The absorbance values $(\mathrm{A})$ were converted into units by the formula

$$
b(\mathrm{U} / \mathrm{l})=\left(\mathrm{A}_{546 \mathrm{~nm}}^{65 \min }-\mathrm{A}_{546 \mathrm{~nm}}^{5 \min }\right) \times 470
$$

Catalytic activity concentrations of lipase (substrate triolein) and amylase (substrate p-nitrophenyl-maltopentaoside and -hexaoside) were measured using the test kits of Boehringer, Mannheim and Behring Werke, Marburg, respectively.

\section{Results}

\section{Evaluation of Optimal Assay Conditions}

Porcine and human enzymes were incubated in the substrate emulsion in order to evaluate optimal test conditions. Since fatty acid liberation was taken as a measure of phospholipase A activity, the oleic acid standard was used for calibration. An average molar lineic absorbance of $1540 \mathrm{~m}^{2} / \mathrm{mol}$ was determined at $546 \mathrm{~nm}$. As shown in table 1, oleic acid added to substrate emulsions at different concentrations was almost completely recovered.

The $\mathrm{pH}$-dependency of phospholipase A activity was tested with TRIS/HCl, TRIS/maleate, sodium phosphate, and sodium acetate (for preparation of buffers see l.c. (7)), covering the range from $\mathrm{pH} 5.5-10$ (fig. 1).

Tab. 1. Recovery of oleic acid added to the phosphatidylcholine emulsion.

\begin{tabular}{lll}
\hline Oleic acid (mmol/l) & & \\
\hline Added & Measured & Expected \\
\hline 0 & 0.08 & - \\
0.09 & 0.16 & 0.17 \\
0.23 & 0.30 & 0.31 \\
0.45 & 0.49 & 0.53 \\
0.91 & 0.91 & 0.99 \\
\hline
\end{tabular}
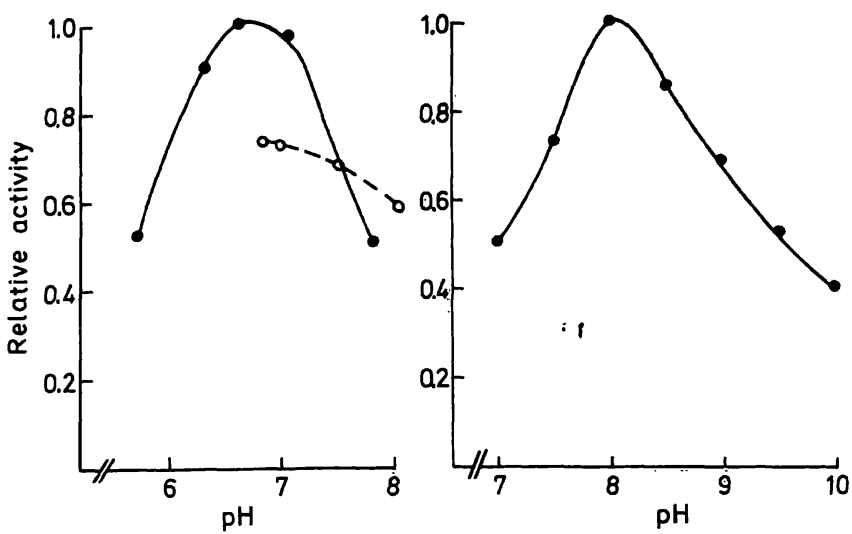

Fig. 1. pH-optima of human and porcine pancreatic phospholipase $\mathrm{A}$.

left side: human enzyme, TRIS/maleate buffer (dotted line: TRIS/HCl buffer)

right side: porcine enzyme, TRIS/HCl buffer.

The $\mathrm{pH}$-optimum was found to be around 8.0 for the porcine and at 6.5 for the human enzyme using 0.1 $\mathrm{mol} / \mathrm{l} \mathrm{TRIS} / \mathrm{HCl}$ and TRIS/maleate buffer (fig. 1). Low activities were obtained with equimolar phosphate and citrate buffers. When $0.1 \mathrm{~mol} / 1$ TRISmaleate buffer, $\mathrm{pH} 6.5$ was used instead of TRIS/ $\mathrm{HCl}$ the activity of the human enzyme was about 20 percent higher and that of the porcine enzyme was reduced to about one third. Increasing TRIS/maleate concentrations up to $0.4 \mathrm{~mol} / \mathrm{l}$ reduced the measurable activity of both enzymes considerably, whereas reduction of buffer concentration had little effect (fig. 2). With TRIS/HCl buffer no such concentration dependence was evident.

The optimal concentration of deoxycholate was attained at $1 \mathrm{mmol} / \mathrm{l}$. Under these conditions, addition of $\mathrm{CaCl}_{2}$ up to $6 \mathrm{mmol} / \mathrm{l}$ did not greatly influence the catalytic activity, probably due to the presence of

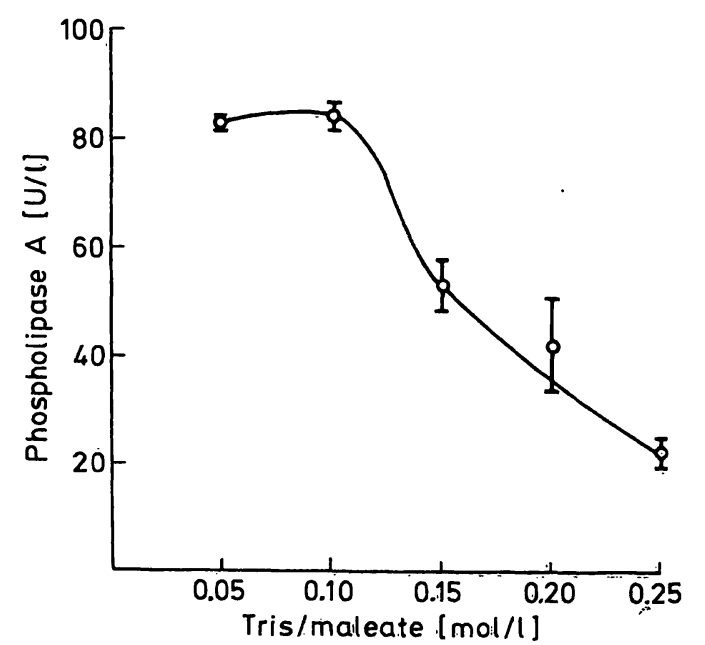

Fig. 2. Inhibition of human pancreatic phospholipase $A$ by increasing concentrations of TRIS/maleate buffer. Each point represents the mean of 2 independent experiments.

J. Clin. Chem. Clin. Biochem. / Vol. 24, 1986 / No. 11 


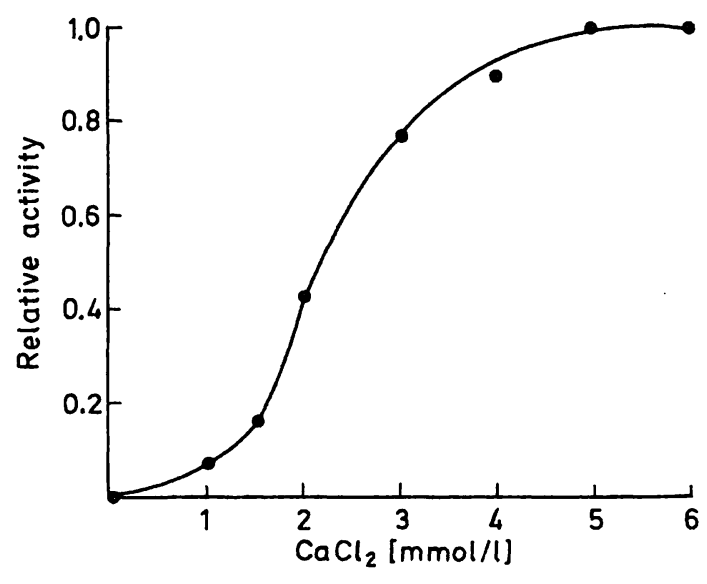

Fig. 3. Reactivation of phospholipase $A$ by calcium chloride in the presence of $2 \mathrm{mmol} / \mathrm{l}$ EDTA.

calcium in the assay mixture (about $0.7 \mathrm{mmol} / \mathrm{l})$. Only in the presence of EDTA, which completely inhibited the catalytic activity, could a clear calcium dependence be demonstrated (fig. 3).

As a prelininary recommendation, the following reaction mixture was chosen for the measurement of porcine as well as human phospholipase $\mathrm{A}$ :

$7.9 \mathrm{mmol} / 1$ phosphatidylcholine, $125 \mathrm{mmol} / \mathrm{l}$ TRIS/ $\mathrm{HCl}, \mathrm{pH} 8.0,1 \mathrm{mmol} / \mathrm{l}$ deoxycholate, $4 \mathrm{mmol} / \mathrm{l} \mathrm{cal}-$ cium chloride, $2.5 \mathrm{~g} / 1$ Triton X-100.

\section{Analytical properties}

The assay was linear for at least 1 hour (fig. 4) if the maximal difference of absorbance did not exceed 0.15 . This corresponds to a liberation of up to 0.4 $\mathrm{mmol} / \mathrm{l}$ fatty acids in the assay mixture.

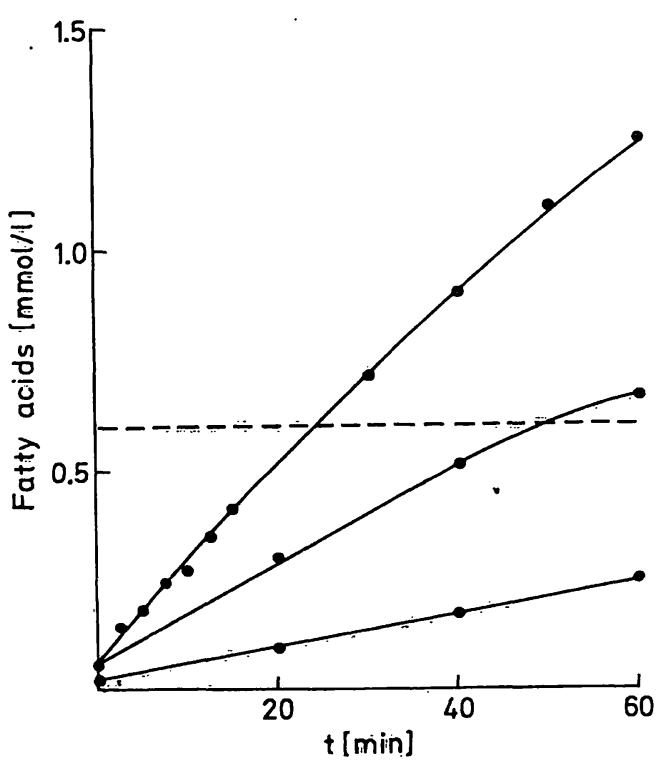

Fig. 4. Linearity of the phospholipase A assay. For further details see results section.

The dotted line represents the recommended dilution limit.
Spontaneous hydrolysis of phosphatidylcholine emulsion was neglegible ("blank activity" $=0$ to $3 \mathrm{U} / \mathrm{l}$ ). Within-run and day-to-day precisions were between 4 and 10 percent respectively (tab. 2).

Tab. 2. Within-run and day-to-day precision $(n=5)$ of the phospholipase assay. A human pool serum was stocked with purified porcine phospholipase $\mathrm{A}_{2}$ and stored frozen at $-20^{\circ} \mathrm{C}$ in $0.1 \mathrm{ml}$ aliquots.

\begin{tabular}{lllr}
\hline & $\begin{array}{l}\text { Mean value } \\
(\mathrm{U} / \mathrm{l})\end{array}$ & $\begin{array}{l}\text { SD } \\
(\mathrm{U} / \mathrm{l})\end{array}$ & $\begin{array}{r}\mathrm{CV} \\
(\%)\end{array}$ \\
\hline Within run & 15.8 & 1.64 & 10.4 \\
& 32.5 & 1.29 & 4.0 \\
Day-to-day & 15.4 & 1.14 & 7.4 \\
& 31.0 & 2.24 & 7.2 \\
\hline
\end{tabular}

The activity concentration measured at $\mathrm{pH} 8.0$ in fasting sera of healthy volunteers was low $(5.8 \pm 2.9$ $\mathrm{U} / \mathrm{l}$, median $=6 \mathrm{U} / \mathrm{l}, \mathrm{n}=14$ ). Preliminary experiments with sera from pancreatitis patients revealed catalytic concentrations between 0 and $110 \mathrm{U} / \mathrm{l}$. There was no significant correlation with lipase or amylase catalytic ąctivity (fig. 5).

A typical example is given in figure 6: enzyme activities were measured in a 44 year old man who was hospitalized because of an attack of acute necrotizing pancreatitis. Despite surgical interventions on the $1^{\text {st }}$, $18^{\text {th }}$, and $46^{\text {th }}$ day and intensive pharmacotherapy he died after 11 weeks of hospitalization. Amylase and lipase activities were highest at the beginning of the disease and fell to normal values later, while phospholipase A remained elevated throughout the time of hospitalization.

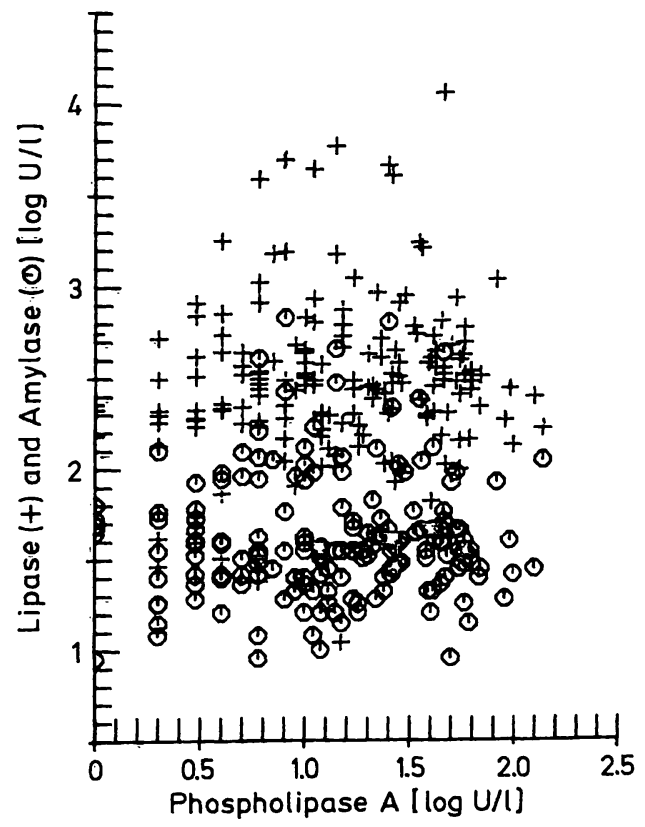

Fig. 5. Correlation of phospholipase A activities with lipase (crosses) and amylase activity (circles) in 176 sera of patients with acute pancreatitis. Activities were transformed to log-scales for clearness. 


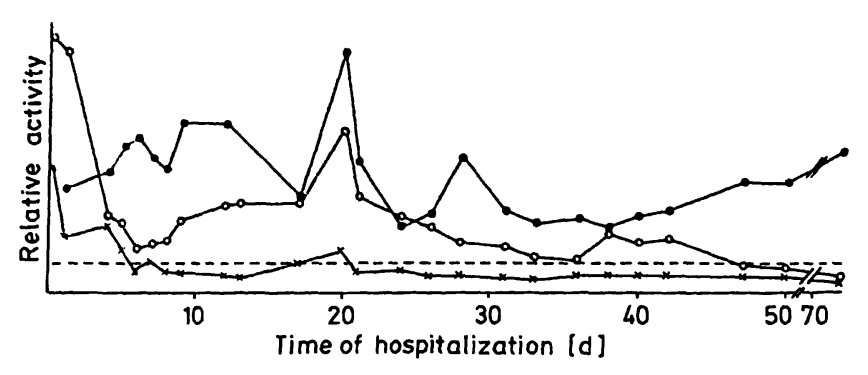

Fig. 6. Activities of phospholipase A $(0-0)$, lipase $(0-0)$, and amylase $(x-x)$ in the serum of a patient who died from an attack of acute necrotizing pancreatitis 11 weeks after admission to the hospital. Relative activities are expressed in terms of the respective upper limit of the normal range (dotted line) for better comparability.

\section{Discussion}

The measurement of phospholipase. A activities in human sera has been hampered so far by the lack of suitable routine methods. Most published procedures are time-consuming and laborious or need special equipment and uncommon reagents. Relatively simple titrimetric assays (8) are not sensitive enough for serum analyses unless incubation times of up to 18 hours are applied (9).

This paper describes a photometric assay as an alternative. The new assay uses only commercially available reagents and normal laboratory equipment. It is sensitive enough to distinguish between normal (up to $10 \mathrm{U} / \mathrm{l}$ ) and elevated activities (up to about $130 \mathrm{U} / \mathrm{l}$ ). It must be noted that the analytical imprecision is relatively high (tab. 2) due to low measuring signals. Duplicate analyses are therefore recommended.

The test conditions which were elaborated for the new assay are similar to those described by other authors for pancreatic and "postheparin-"phospholipase $A(5,8,10)$. Lysosomal leukocyte phospholipase $A_{2}$ seems to be active at acid $\mathrm{pH}$ (11). The activities of about $0-10 \mathrm{U} / 1$, which were found in normal human sera, are higher than those reported by others. Vogel \& Zieve (9) obtained a normal range around $1 \mathrm{U} / 1$ using a titrimetric method. The mean normal values of Miwa et al. (12) and Thuren et al (13) were even below $0.1 \mathrm{U} / 1$ as measured with an isotopic and a fluorometric assay. These differences are most probably due to differences in the physicochemical properties of phospholipid substrates used. Moreover, very different $\mathrm{pH}$-values ranging from $\mathrm{pH} 5(13)$ to $\mathrm{pH} 9(6,14)$ have been found to be optimal for the action of human pancreatic phospholipase $A_{2}$. Further studies will be needed to clarify this discrepancy. The test conditions given here are suitable for the measurement of human as well as porcine phospholipase A. This is useful, since commercial enzyme preparations are often of porcine origin, and the pig is a widely used animal model for experimental pancreatitis.

In the literature, there are some contradictory reports as to whether serum phospholipase $\mathrm{A}$ activities parallel those of lipase and amylase $(15)$ or not $(13,16)$. Our data ((17), this paper) indicate that phospholipase A does not necessarily behave in the same manner as other pancreatic enzymes. It is interesting that the serum concentrations of the enzyme protein of phospholipase $A_{2}$, as measured by immunological assays, usually parallel the activities of amylase in cases of acute pancreatitis and pancreatic cancer (18). Since these determination methods do not distinguish between active phospholipase and its inactive proenzyme $(14,18)$, the following working hypothesis may be established: In a variety of diseases where pancreatic enzymes are released into the blood stream, the enzyme pattern in serum resembles that of the non-injured pancreas, i.e. amylase and lipase are found at high catalytic concentrations, while phospholipase $A_{2}$ is predominant as inactive proenzyme. In severe cases, characterized by activation of proenzymes $(2,3)$, the total proportion of phospholipase protein may rise less markedly than its active form. Furthermore, phospholipases of non-pancreatic origin $(11,19)$ may interfere with either method due to common immunological and catalytic properties.

Several clinical studies are presently in progress to investigate in more detail the postulated importance and prognostic potency $(2,3,19)$ of phospholipase $A$ activity in serum.

\section{Acknowledgement}

The authors wish to thank Mrs. Bentele, Dr. Neumann, Dr. Ziegenhorn, Dr. Wulff, and Dr. Poppe from Boehringer, Mannheim for technical and scientific support of this work. 


\section{References}

1. Hölbing, N., El Kalak, H., Georgopoulos, A., Stilianu, L. \& Hacker, G. (1985) Res. Exp. Med. 185, 131 - 137.

2. Creutzfeldt, W. \& Schmidt, H. (1970) Scand. J. Gastroent. Suppl. 6, 47-62.

3. Nevalainen, T. (1980) Scand. J. Gastroent. 15, 641-650.

4. Hoffmann, G. E., Schmidt, D. \& Bastian, B. (1985) J. Clin. Chem. Clin. Biochem. 23, 582- 583.

5. Shakir, K. M. M. (1981) Anal. Biochem. 114, 64-70.

6. Eskola, J. U., Nevalainen, T. J. \& Aho, H. J. (1983) Clin. Chem. 29, 1772-1776.

7. Documenta Geigy, Wissenschaftliche Tabellen (1971) Ciba Geigy Ltd., Basel, pp. 274-276.

8. Figarella, C. \& Ribeiro, T. (1971) Scand. J. Gastroent. 6, $133-137$.

9. Zieve, L. \& Vogel, W. C. (1961) J. Lab. Med. 57, 586599.

10. Grataroli, R., De Caro, A., Guy, O., Amic, J. \& Figarella, C. (1981) Biochimie 63, 677-684.

11. Ghiara, P., Meli, R., Parente, C. \& Persico, P. (1984) Biochem. Pharmacol. 33, 1445-1450.

12. Miwa, M., Kubota, I., Ichihashi, T., Motojima, H. \& Matsumoto, M. (1984) J. Biochem. 96, 761-773.

13. Thuren, T., Virtanen, J. A., Lalla, M. \& Kinnunen, P. K. J. (1985) Clin. Chem. 31, 714-717.

14. Nishijima, J., Okamoto, M., Ogawa, M., Kosaki, G. \& Yamano, T. (1983) J. Biochem. 94, 137-147.

15. Zieve, L., Vogel, W. \& Kelley, W. D. (1963) J. Appl. Physiol. $18,77-82$.

16. Schröder, T., Kivilaakso, E., Kinnunen, P. K. \& Lempinen, M. (1980) Scand. J. Gastroent. 15, 633-636.

17. Hoffmann, G. E., Schmidt, D. \& Bastian, B. (1985) Diagnose \& Labor 35, 56-61.

18. Nevalainen, T. J., Eskola, J. U., Aho, A. J., Havia, T., Lövgren, T. \& Näntö, V. (1985) Clin. Chem. 31, 11161120.

19. Vadas, P. (1984) J. Lab. Clin. Med. 104, 873-881.

Dr. G. Hoffmann

Städt. Krankenhaus München-Bogenhausen

Institut für Klinische Chemie

Englschalkinger Str. 77

D-8000 München 81 
